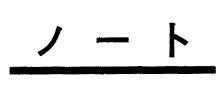

\title{
液体中での石英及びポリ塩化ビニリデン板と ポリマー粒子の相互凝集
}

\author{
後藤 景子* ・ 朝原 功恵 ${ }^{* * 1}$ ・佐々木千絵 ${ }^{* * 2}$ ・田川美恵子 ${ }^{* *}$ \\ * 京都教育大学教育学部 ( $\mathbf{T} 612$ 京都市伏見区深草藤森町 1 ) \\ ** 奈良女子大学生活環境学部（广630 奈良市北魚屋東町）
Mutual Coagulation of Polymer Particles and Quartz or Polyvinylidene Chloride Plates in Liquids

\begin{abstract}
Keiko GotoH*, Norie AsAharA**, Chie SASAKI**, and Mieko TAGAWA**
* Kyoto University of Education (1 Fukakusa-Fujinomori-cho, Fushimi-ku, Kyoto, T612)

** Nara Women's University (Kita-Uoya-Higashi-machi, Nara-shi, $\mathbf{T} 630$ )
\end{abstract}

Mutual coagulation of substrates and particles has been investigated in various liquids. Spherical polyethylene or nylon 12 particles and polyvinylidene chloride or quartz substrates were used. The number of particles adhering to a substrate as a measure of mutual coagulation was small in $n$-alcohols, whereas large in $n$-alkanes, carbon tetrachloride and water. Mutual coagulation decreased with increasing ethanol concentration in ethanol/water mixtures. The experimental results were not explained on the basis of the heterocoagulation theory, suggesting that the polar interaction affected mutual coagulation. The results are discussed from the standpoint of liquid dielectric constants as a measure of polarity. Mutual coagulation in the present systems was found to occur hardly in the liquids whose relative dielectric constants ranged from 20 to 60 .

\section{1 緒 言}

液体中での平板基質に対する固体粒子の付着は本質的 には基質と粒子の相互凝集であり, 種々の因子の影響を 受ける。その因子に関して, 著者らはこれまでに石英や 繊維基質に対する種々の粒子の付着に及ぼす表面電 位 $^{1) \sim 3)}$, Hamaker 定数 ${ }^{3) \sim 5)}$, 吸着層 ${ }^{5)}$, イオン強 度6)の影響について調べ, また, 界面活性剤存在下にお ける粒子の脱離現象 ${ }^{7), 8)}$, 二次極小での付着之脱離の 活性化エネルギー9)について検討してきた。また, 最 近, 水中での種々高分子板に対する粒子の付着・脱離率 がエタノールの添加により大きく影響されることを見い だしており ${ }^{10)}$, 粒子, 基質および液体の極性が付着・ 脱離現象に関与していることが示唆された。このこと

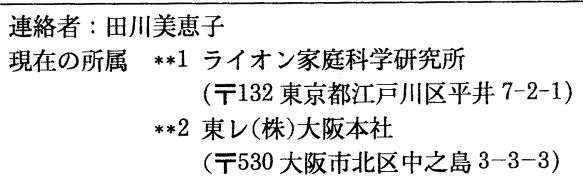

は，基質に対する粒子の付着現象が液体の極性をパラ メーターとして制御できる可能性を示していると解釈さ れる。

そこで本研究では, 極性の異なる各種液体中における 粒子の付着現象を調べた。また, 脱離現象を調べこと で，付着をよりよく理解することができ，かつ，実用的 にも役立つ情報が得られるので，これについても若干の 検討を試みた。

\section{2 実 験}

\section{$2 \cdot 1$ 試 料}

粒子として, ポリエチレン粒子とナイロン 12 粒子を 用いた。いずれも球形で，平均直径はそれぞれ $4 \mu \mathrm{m}^{4)}$ と $5 \mu \mathrm{m}^{1}$ )である。基質にはポリ塩化ビニリデン板（厚 さ $0.78 \mathrm{~mm}$ ) および石英板（厚さ $1 \mathrm{~mm}$ ) を用いた。 粒子およびポリ塩化ビニリデン板は水, エ夕ノール, エ チルエーテルに順次浸漬して精製を行った。石英板およ びガラス器具はガラス器具用洗浄剤水溶液に浸漬して流 水したのち, クロム硫酸混液に浸漬して流水し, 水蒸気 
洗浄を行ってから実験に供した。

媒質として用いた液体は水, $n$-アルコール（メタノー ル, エタノール, プロパノール, ブタノール, ペンタ ノール), 1, 4-ジオキサン, $n$-アルカン (ヘキサン, オ クタン, デカン, ドデカン, テトラデカン, ヘキサデカ ン), 並びに四塩化炭素である。水は再蒸留水を, その 他の液体は化学用特級品をそれぞれ用いた。

\section{$2 \cdot 2$ 粒子の付着および脱離}

各液体中にポリエチレン粒子またはナイロン粒子を超 音波照射により分散させ, 分散液 $(15 \mathrm{~mL})$ 中に基質 $\left(2.5 \times 1.0 \mathrm{~cm}^{2}\right)$ を垂直に浸漬し, 分散液をゆっくりと かくはんした。粒子濃度はポリエチレン粒子は $0.1 \mathrm{~g} /$ $\mathrm{dm}^{3}\left(3.2 \times 10^{9}\right.$ 個 $\left./ \mathrm{dm}^{3}\right)$, ナイロン粒子は $0.2 \mathrm{~g} / \mathrm{dm}^{3}$ $\left(3.0 \times 10^{9}\right.$ 個 $\left./ \mathrm{dm}^{3}\right)$ とした。 $60 \mathrm{~min}$ 後 ${ }^{10), 11)}$ に基質を 取り出して, 粒子の存在しない分散媒 $15 \mathrm{~mL}$ 中で $30 \mathrm{~s}$ の浸漬を 2 回行ったのち風乾し, 光学顕微鏡を用いて付 着粒子数 $n_{\mathrm{a}}$ を 96 視野について計数した ${ }^{10), 11) 。 ~}$

脱離実験は, 水分散液を用いて上記の方法で基質に粒 子を付着させたのち, 相対湿度 $20 \%$ に調整したデシ ケーター中で $1 \mathrm{~h}$ 乾燥させた基質を用いて行った。あら かじめ $n_{\mathrm{a}}$ を調べた基質を脱離液 $15 \mathrm{~mL}$ 中に垂直に浸 漬し, $60 \mathrm{~min}$ 脱離液をゆるやかにかくはんしたのち基 質に付着して残っている粒子数 $n_{\mathrm{r}}$ を計数した ${ }^{10), 11) 。 ~}$ 以上により, 脱離率 $\left(n_{\mathrm{a}}-n_{\mathrm{r}}\right) / n_{\mathrm{a}}$ を求めた。

\section{$2 \cdot 3 \zeta$ 電位測定}

液体中における粒子と基質の $\zeta$ 電位は，それぞれ顕微

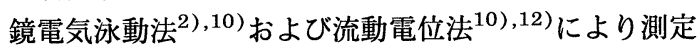
した。

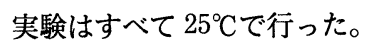

\section{3 結果及び考察}

水, 各種アルコール, $n$-デカンおよび四塩化炭素中 で得られた付着粒子数 $n_{\mathrm{a}}$, 並びに脱離率 $\left(n_{\mathrm{a}}-n_{\mathrm{r}}\right) / n_{\mathrm{a}}$ を Table-1 に示す。いずれの粒子と基質の組み合わせで もエタノール中で $n_{\mathrm{a}}$ が最も小さく, 付着抑制効果が大 きかった。なお，本実験に用いたどの $n$-アルコール中 でも $n_{\mathrm{a}}$ は小さかったが, 付着抑制効果が最も大きかっ たのはエタノールであった。Table-1 の結果から, 水 にエタノールを加えると $n_{\mathrm{a}}$ が隇少することが予想され るので, 水/エタノール混合液中での付着粒子数を調べ た。エタノールの体積混合率と $n_{\mathrm{a}}$ の関係を Fig. -1 に 示す。エ夕ノールの体積混合率が増加すると $n_{\mathrm{a}}$ が減少 し, $30 \%$ 以上ではほとんど付着が起こらないことがわ かった。ジオキサンを水に添加しても，ジオキサン混合 率が増すと $n_{\mathrm{a}}$ が小さくなり, 同じような付着抑制効果 が認められた（例えばジオキサン混合率 $10 \%$ のときポ リエチレン粒子ーポリ塩化ビニリデン板系で $n_{\mathrm{a}}$ は 3.66 $\times 10^{3} \mathrm{~cm}^{-2}$ であった)。

Table-1 Number of particles adhering to a plate, $n_{\mathrm{a}}$, particle removal efficiency from a plate, $\left(n_{\mathrm{a}}-n_{\mathrm{r}}\right) / n_{\mathrm{a}}$, in a liquid.

\begin{tabular}{l|l|l|c|c}
\hline \multicolumn{1}{c|}{ Liquids } & Particles & Plates & $n_{\mathrm{a}}\left(\times 10^{-3} \mathrm{~cm}^{-2}\right)$ & $\left(n_{\mathrm{a}}-n_{\mathrm{r}}\right) / n_{\mathrm{a}}$ \\
\hline Water & Polyethylene & PVDC & 15.7 & 0.20 \\
Water & Polyethylene & Quartz & 5.8 & 0.40 \\
Water & Nylon & PVDC & 5.7 & 0.35 \\
Water & Nylon & Quartz & 2.8 & 0.51 \\
Methanol & Polyethylene & PVDC & 0.3 & \\
Ethanol & Polyethylene & PVDC & 0.04 & 0.92 \\
Ethanol & Polyethylene & Quartz & 0.04 & 0.96 \\
Ethanol & Nylon & PVDC & 0.02 & 0.97 \\
Ethanol & Nylon & Quartz & 0.01 & 0.96 \\
1-Propanol & Polyethylene & PVDC & 0.48 & \\
1-Butanol & Polyethylene & PVDC & 0.59 & \\
1-Pentanol & Polyethylene & PVDC & 0.54 & \\
$n$-Decane & Polyethylene & PVDC & 43.9 & 0.06 \\
$n$-Decane & Polyethylene & Quartz & 38.3 & 0.04 \\
$n$-Decane & Nylon & PVDC & 3.4 & 0.05 \\
$n$-Decane & Nylon & Quartz & 8.1 & 0.01 \\
Carbon tetrachloride & Polyethylene & PVDC & 15.4 & 0.16 \\
Carbon tetrachloride & Polyethylene & Quartz & 14.4 & 0.06 \\
Carbon tetrachloride & Nylon & PVDC & 2.6 & 0.15 \\
Carbon tetrachloride & Nylon & Quartz & 8.0 & 0.04 \\
\hline
\end{tabular}




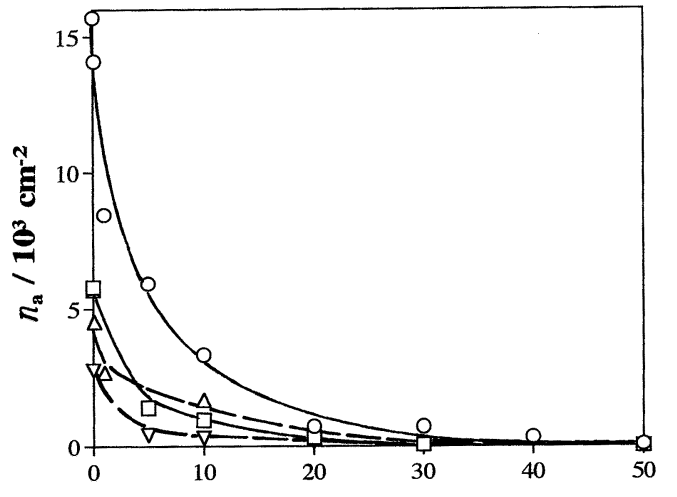

Volume ratio of ethanol (\%)

$\bigcirc$ : polyethylene particle-PVDC plate, $\square$ : polyethylene particle-quartz plate, $\triangle$ : nylon particle-PVDC plate, $\nabla$ : nylon particle-quartz plate Fig. -1 Number of particles adhering to a plate, $n_{\mathrm{a}}$, in a ethanol/water mixture as a function of volume ratio of ethanol.

Table-1 において, $n$-デカン中でのポリエチレン粒 子の $n_{\mathrm{a}}$ が大きい值を示している。デカン以外のアルカ ン中でも $n_{\mathrm{a}}$ の值は大きく, 炭素数が増加すると $n_{\mathrm{a}}$ が 減少する傾向が得られた。

脱離率 $\left(n_{\mathrm{a}}-n_{\mathrm{r}}\right) / n_{\mathrm{a}}$ はエ夕ノール中で大きく, $n$-デカ ンおよび四塩化炭素中で小さくなった (Table-1)。水 にエタノールを混合したときの脱離率は, Fig.-2 に示 すように，エタノール混合率 0３0％で脱離率の変化 が大きく, $30 \%$ を越えるとエ夕ノール $100 \%$ (Table-1) とほぼ同程度となり，ほとんどの粒子が脱離した。

本研究で得られた各種液体中での付着粒子数之脱離率 を比較すると, 付着が起こりにくい液体中で脱離が起こ りやすく, 逆に, 付着が起こりやすい液体中で脱離が起 こりにくいという傾向が認められる。このことは付着と 脱離が互いに逆の過程とみなせることを示しており，本 研究のように単純化した系で得られた粒子の付着・脱離

Table-2 The $\zeta$-potentials, overall Hamaker constants, $A$, and maxima in the total potential energy of curves, $V_{\text {Tmax }}$, in the water/ethanol mixture-polyethylene particle-polyvinylidene chloride plate system.

\begin{tabular}{c|c|c|c|c}
\hline $\begin{array}{c}\text { Ethanol } \\
(\%)\end{array}$ & $\zeta$-Potentials $(\mathrm{mV})$ & $\mathrm{A}$ & $\begin{array}{c}V_{\text {Tmax }} \\
\left(\times 10^{-3} \mathrm{kT}\right)\end{array}$ \\
\cline { 2 - 4 } & Particles & Plates & $\left(\times 10^{22} \mathrm{~J}\right)$ & $\left(\times 10^{2}\right.$ \\
\hline 0 & -31.5 & -34.4 & 0.29 & 3.22 \\
10 & -30.8 & -37.9 & 2.43 & 3.04 \\
20 & -27.4 & -39.9 & 4.12 & 2.48 \\
30 & -23.5 & -44.8 & 5.66 & 1.71 \\
40 & -10.6 & -39.5 & 7.18 & 0.33 \\
\hline
\end{tabular}

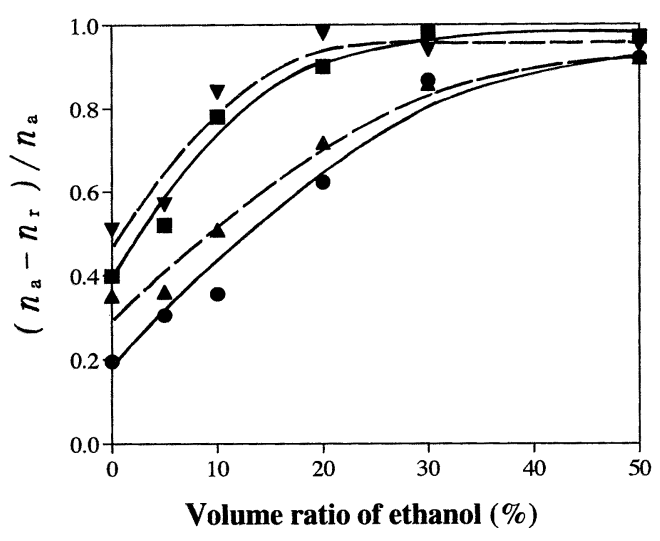

: polyethylene particle-PVDC plate, $\mathbf{\square}$ : polyethylene particle-quartz plate, $\boldsymbol{\Delta}$ : nylon particle-PVDC plate, $\boldsymbol{\nabla}$ : nylon particle-quartz plate Fig.-2 Particle removal efficiency from a plate $\left(n_{\mathrm{a}}-n_{\mathrm{r}}\right) / n_{\mathrm{a}}$, in a ethanol/water mixture as a function of volume ratio of ethanol.

現象が粒子一基質間相互作用に支配されていることを意 味している。

次に, 得られた実験結果をへテロ凝集理論 ${ }^{2)} に よ り$ 検 討した。表面電位の近似値にと電位を用いて静電相互作 用ポテンシャルエネルギーを, 液体中における粒子一基 質間の全 Hamaker 定数を用いて London-van der Waals 相互作用のポテンシャルエネルギーを算出し, 両者の和から全相互作用ポテンシャルエネルギー曲線を 求めた。

水/エタノール混合液中でのポリ塩化ビニリデン板と ポリエチレン粒子間の全相互作用ポテンシャルエネル ギ一極大 $V_{\mathrm{T} \text { max }}$ を, 計算に用いた $\zeta$ 電位と全 Hamaker 定数とともに Table-2 に示す。ここで全 Hamaker 定数は, 真空中における液体, 粒子, 基質の Hamaker

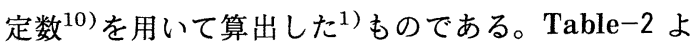
り，エタノール濃度が増すと， $V_{\mathrm{T} \max }$ が減少する傾向 が認められる。 $V_{\mathrm{T} \max }$ は粒子付着のエネルギー障壁に 相当するので, 計算結果からはエタノール濃度が増すと 付着粒子数が多くなると考えられるが, 実験結果 (Fig.-1) はこれと逆の傾向を示している。このこと は, 本研究での付着現象がへテロ凝集理論を用いて説明 することができないことを意味しており, 静電相互作用 と London-van der Waals 相互作用以外の相互作用が 関与していることを示唆している。

水/エタノール混合液の表面自由エネルギーの極性成 分はエ夕ノール濃度が増すと減少する傾向をもつ ${ }^{13)}$ 。 したがって水へのエタノール添加による付着粒子数の減 少は, 液体の極性の減少により極性相互作用が変化した ためではないかと思われる。そこで液体の極性と関係す るパラメーターとして誘電率をとりあげる。 


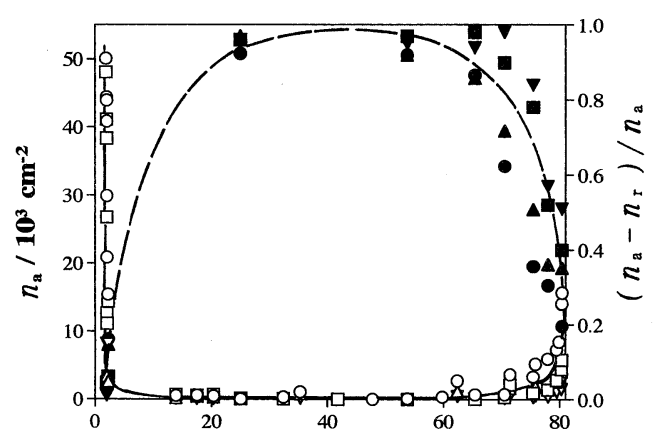

Relative dielectric constant

$\bigcirc$, polyethylene particle-PVDC plate, $\square$ polyethylene particle-quartz plate, $\triangle, \mathbf{\Delta}$ : nylon particle-PVDC plate, $\nabla, \boldsymbol{\nabla}$ : nylon particlequartz plate

Fig. -3 Effect of relative dielectric constant of a liquid on number of particles adhering to a plate, $n_{\mathrm{a}}(\bigcirc, \square, \triangle, \nabla)$, and particle removal efficiency from a plate, $\left(n_{\mathrm{a}}-n_{\mathrm{r}}\right) /$ $n_{\mathrm{a}}(\mathbf{O}, \mathbf{\square}, \boldsymbol{\nabla})$.

誘電率は物質に電場を与えたときに起こる正電荷と負 電荷の微視的ずれの程度を表しており, 分子の分極率や 双極子モーメントと関係している。そこで各種液体中で 得られた付着粒子数および脱離率について, 誘電率との 関係を Fig.-3 に示す。ここで比誘電率には文献値 ${ }^{14)}$ を用いた。ただし, $n$-ヘプタン以外の $n$-アルカンの比 誘電率は, 誘電率が屈折率の 2 乗に比例するとして, $n$ ヘプタンの比誘電率と各 $n$-アルカンの屈折率の值 ${ }^{15}$ ) ら算出した。Fig.-3 において, 比誘電率が 20〜60 程 度の值をもつ液体中で粒子の付着が抑えられ, かつ, 粒 子が脱離しやすい傾向が認められた。

\section{4 結 論}

各種液体中での粒子の付着・脱離現象を調べた。 $n-$ アルカン中では粒子は付着しやすく, かつ, 脱離しにく かった。また, 水中に比べて $n$-アルコール中では粒子 は付着しにくく，とくにエタノール中では最も付着が抑 制されることがわかった。水にエタノールを混合する と, 混合率の増加に伴って付着粒子数が減少し, 混合率 $30 \%$ 以上では粒子はほとんど付着しなかった。脱離率 は水中では低いが, 水にエタノールを添加すると増大
し，エ夕ノール $100 \%$ ではほとんどの粒子が脱離した。 付着粒子数および脱離率と液体の比誘電率の関係をプ ロットしたところ, 比誘電率が 20６0 の液体中で付着 が抑えられ，かつ脱離が起こりやすいという結果が得ら れた。本研究に用いた試料の表面自由エネルギーの極性 成分は, 3〜44 $\mathrm{mJ} / \mathrm{m}^{2}$ 16)の範囲にあり, 粒子と基質 のどの組み合わせにおいても，20～60 の比誘電率をも つ液体中で粒子付着が抑えられるという本実験結果は, 3〜44 $\mathrm{mJ} / \mathrm{m}^{2}$ の表面自由エネルギーの極性成分をもつ 他の物質に関しても同じような結果が得られる可能性を 示唆している。この知見は実用的立場から粒子の付着制 御を行うための一つの指針を与えると思われる。

平成 7 年 (1995 年) 2 月 8 日受理]

\section{文 献}

1) K. Gotoh, M. Iriya, A. Mitsui, M. Tagawa, Colloid \& Polymer Sci., 261, 805 (1983)

2) K. Gotoh, T. Inoue, M. Tagawa, Colloid \& Polymer Sci., 261, 982 (1984)

3) M. Tagawa, K. Gotoh, M. Yokokura, A. Syutoh, S. Takechi, Colloid \& Polymer Sci., 267, 434(1989)

4) 田川美恵子, 中田由美子, 後藤景子, 油化学, 38,88 (1989)

5) K. Gotoh, E. Takahashi, M. Maekawa, M. Tagawa, J. Adhesion Sci., Technol., 8, 211 (1994)

6) 中田由美子, 後藤景子, 田川美恵子, 油化学, 38,626 (1989)

7) K. Gotoh, M. Chisaki, M. Tagawa, J. Jpn. Oil Chem. Soc., 35, 300 (1986)

8) M. Tagawa, K. Gotoh, Colloid \& Polymer Sci., 264, 1072 (1986)

9) K. Gotoh, Y. Nakata, M. Tagawa, Colloid \& Polymer Sci., 270, 794 (1992)

10) K. Gotoh, C. Kako, T. Yoshimura, M. Tagawa, J. Adhesion Sci., Technol., 7, 467 (1993)

11）後藤景子, 中田由美子, 黒目智子, 小野登希恵, 田川美 恵子, 油化学, 41, 1220 (1992)

12) R. Takagi, M. Tagawa, K. Gotoh, M. Nakagaki, J. Membrane Sci., 92, 229 (1994)

13) J.R. Dann, J. Colloid Interface Sci., 32, 302 (1970)

14）“化学便覧 II”, 日本化学会編, 丸善, 東京 (1984) p. 502

15）“化学大辞典”, 大木道則ら編, 東京化学同人, 東京 (1989)

16) M. Tagawa, K. Gotoh, A. Yasukawa, M. Ikuta, Colloid \& Polymer Sci., 268, 589 (1990) 